\title{
ERRATUM
}

\section{FIRST RADIOCARBON CHRONOLOGY FOR THE EARLY IRON AGE SITES OF CENTRAL KAZAKHSTAN (TASMOLA CULTURE AND KORGANTAS PERIOD) - ERRATUM}

Arman Z Beisenov • Svetlana V Svyatko • Aibar E Kassenalin • Kairat A Zhambulatov $\bullet$ Daniyar Duisenbai $\bullet$ Paula J Reimer

doi: 10.1017/RDC.2015.18. Published by Cambridge University Press, 2016.

In Beisenov, Svyatko, Kassenalin, Zhambulatov, Duisenbai, and Reimer (2016) page 179, the address for Arman Beisenov, Kairat A Zhambulatov, and Daniyar Duisenbai should instead have been listed as Institute of Archaeology n.a. A. Kh. Margulan, 44 Avenue Dostyk, st. Shevchenko 28, Almaty 050010, Kazakhstan.

We sincerely regret the error and any problems that have resulted for the authors and readers.

\section{REFERENCE}

Beisenov Arman Z, et al. 2016. First Radiocarbon Chronology for the Early Iron Age Sites of Central Kazakhstan (Tasmola Culture and Korgantas Period). 58(1):179-91. 